\title{
PENGARUH LAMA WAKTU PENCELUPAN FILLET IKAN NILA (Oreochoromis niloticus) PADA NITROGEN CAIR TERHADAP pH, TEKSTUR, DAN PROTEIN PADA PEMBEKUAN
}

\section{EFFECT OF TIME IMMERSION IN TILAPIA FILLETS (Oreochoromis niloticus) IN LIQUID NITROGEN AGAINST pH, TEXTURE, AND PROTEIN IN FREEZING}

\author{
Elis Setyawati ${ }^{1}$, Dewi Larasati ${ }^{2}$ dan Sri Haryati ${ }^{3}$ \\ Fakultas Teknologi Pertanian Universitas Semarang, Semarang
}

\begin{abstract}
ABSTRAK
Nitrogen cair merupakan salah satu metode pembekuan yang hanya menggunakan waktu yang sangat singkat dengan titik didih yang mencapai -195 oC. Nitrogen cair lebih efektif dibandingkan dengan pendingin berbahan amoniak maupun freon pembekuan yang sangat cepat akan menghasilkan kristal es yangsangat kecil tersusun secara merata pada jaringan. Tujuan dari penelitian ini adalah untuk mengetahui pengaruh proses pembekuan dengan menggukanan freezer dan nitrogen cair terhadap $\mathrm{pH}$, protein, tekstur. Manfaat pembekuan dengan nitrogen cair adalah dapat menghambat pertumbuhan mikroba didalam produk makanan.Rancangan percobaan yang digunakan dalam penelitian ini adalah Rancangan Acak Kelompok (RAK) satu faktor yaitu metode pembekuan. yaitu P1 : pembekuan denganmenggunakan freezer selama 24 jam, P2 : pembekuan dengan menggunakan nitrogencair selama 20 detik, P3 : pembekuan dengan menggunakan nitrogen cair selama 40detik, P4 : pembekuan dengan menggunakan nitrogen cair selama 60 detik dan diulang sebanyak 5 kali. Data dianalisis dengan ANOVA dan diuji menggunakan Duncan Multiple Range Test pada taraf a 5\%. Hasil penelitian menujukkan bahwa lama pencelupan fillet ikan kedalam nitrogen cair pada hari ke-0 berpengaruh nyata $(\mathrm{p}<0,05) \mathrm{pH}$, tekstur, protein. Hari ke-7 berpengaruh nyata $(\mathrm{p}<0,05)$ terhadap protein tetapi tidak berpengaruh nyata terhadap $\mathrm{pH}$, tekstur. Perlakuan terbaik pada hari ke-0 terdapat pada perlakuan P2 dengan lama waktu pencelupan 20 detik, sedangkan pada hari ke-7 terdapat pada perlakuan P3 dengan lama waktu pencelupan 40 detik. Hasil pengujian kadar air pada hari ke-0 pH hari ke-0 6,12; hari ke-7 6,10, \%, tekstur hari ke-0 4112,21 gf; hari ke-7 3124,00 gf, protein hari ke-0 21,14\%; hari ke-7 20,80\%. Perlakuan lama waktu pencelupan yang terbaik pada hari ke-0 terdapat pada perlakuan P2 dengan lama waktu pencelupan 20 detik, sedangkan pada hari ke-7 terdapat pada perlakuan P3 dengan lama waktu pencelupan 40 detik dengan kualitas mutu yang masih bisa dipertahankan setelah dilakukan penelitian uji $\mathrm{pH}$, tekstur dan protein pada fillet ikan yang dicelupkan kedalam Nitrogen cair.
\end{abstract}

Kata Kunci : pembekuan, nitrogen cair. 


\begin{abstract}
Liquid nitrogen is a freezing method that only uses a very short time with a boiling point reaching $-195^{\circ} \mathrm{C}$. Liquid nitrogen is more effective compared to coolers made from ammonia and freezing very quickly will produce very small ice crystals arranged evenly on the network. The purpose of this study was to determine the effect of the freezing process by using freezer and liquid nitrogen on $\mathrm{pH}$, protein, texture. The benefit of freezing with liquid nitrogen is that it can inhibit the growth of microbes in food products. The experimental design used in this study was a one-factor Randomized Block Design (RBD), the freezing method. namely P1: freezing using a freezer for 24 hours, P2: freezing using liquid nitrogen for 20 seconds, P3: freezing using liquid nitrogen for 40 seconds, P4: freezing using liquid nitrogen for 60 seconds and repeated 5 times. Data were analyzed by ANOVA and tested using Duncan Multiple Range Test at a level of 5\%. The results showed that the length of immersion of fish fillets into liquid nitrogen on day 0 significantly affected $(p<0.05) p H$, texture, protein. Day 7 had a significant effect $(p<0.05)$ on protein but did not

significantly affect $\mathrm{pH}$, texture. The best treatment on day 0 was on $\mathrm{P} 2$ treatment with a dipping time of 20 seconds, while on day 7 there was treatment on P3 with a dipping time of 40 seconds. The results of testing the water content on day $0 \mathrm{pH}$ day 0, 6.12; 7 th day 6.10\%, texture Oth day $4112.21 \mathrm{gf}$; 7 th day $3124.00 \mathrm{gf}$, protein $0^{\text {th }}$ day $21.14 \%$; 7 th day $20.80 \%$. The best immersion time treatment on day 0 is on P2 treatment with 20 seconds immersion time, while on the 7th day there is treatment on P3 with 40 seconds immersion time with quality that can still be maintained after a pH test has been done. , texture and protein in fish fillets dipped in liquid nitrogen.
\end{abstract}

Keywords: freezing, liquid nitrogen.

\title{
PENDAHULUAN
}

Ikan merupakan salah satu jenis ikan budidaya air tawar yang mempunyai prospek cukup baik untuk dikembangkan karena banyak digemari oleh masyrakat. Fillet ikan merupakan irisan daging tanpa tulang, diperoleh dengan cara menyayat ikan utuh sepanjang tulang belakang, dimulai dari belakang kepala sampai ekor pada tulang belakang (Moeljanto, 1992). Produk fillet ikan nila lebih rentan terhadap kontaminasi dan penurunan mutu dibandingkan dengan ikan utuh, sehingga diperlukan penanganan yang cepat dan tepat (Irianto dan Soesilo, 2007)

Pembekuan merupakan salah satu metode untuk memperpanjang umur simpan. Teknologi pembekuan ini cukup sederhana dan tidak menyita waktu, namun dapat menghambat pertumbuhan bakteri, kapang, dan khamir yang menyebapkan kerusakan terhadap produk pangan. Dibandingkan dengan metode pemanasan, pembekuan merupakan metode yang dapat dilaksanakan dengan cepat dan mampu mempertahankan nutrisi bahan apabila dilakukan dengan benar. Ada beberapa metode pembekuan cepat yang dapat digunakan, dengan dilakukan perendaman langsung kedalam cairan pendingin atau dengan menyemprotkan cairan pendingin diatas makanan. 
Nitrogen cair dengan titik didihnya $-196^{\circ} \mathrm{C}$ mempunyai kemampuan membekukan bahan organic relative lebih efektif dibandingkan dengan pendingin berbahan Freon maupun amoniak (Xu et al, 2001).

\section{BAHAN DAN METODE}

Penelitian ini berlangsung selama bulan Juni - Juli 2019. Penelitian ini di Laboratorium Rekayasa Pangan, Laboratorium Kimia, dan Laboratorium Mikrobiologi Fakultas Teknologi Pertanian Universitas Semarang. Bahan baku yang digunakan adalah ikan nila yang diperoleh dari pengepul ikan yang bertempat di Jl. Cempedak Raya No.4 Lamper Semarang Selatan. Nitrogen cair diperoleh dari balai inseminasi buatan (BIB) ungaran semarang. Rancangan percobaan yang digunakan dalam penelitian ini adalah rancangan acak kelompok (RAK) dengan satu faktor, yaitu dengan lama waktu pencelupan. Dengan 4 perlakuan dan diulang sebanyak 5 kali. P1 : Pembekuan dengan menggunakan Freezer. P2 : Pencelupan dengan menggunakan Nitrogen cair selama 20 detik, P3 : Pencelupan dengan menggunakan Nitrogen cair selama 40 detik, P4 : Pencelupan dengan menggunakan Nitrogen cair selama 60 detik. Parameter yang diamati yaitu $\mathrm{pH}$, protein, tekstur. Data yang diperoleh dianalisa dengan menggunakan ANOVA dan apabila ada perbedaan yang nyata maka akan dilanjut dengan Duncan Multiple Range Test pada taraf $\alpha 5 \%$. Pengamatan dilakukan terhadap karakteristik mutu kimia yang meliputi (1) $\mathrm{pH}$, diukur dengan $\mathrm{pH}$ meter (AOAC 2005), (2) tekstur, pengukuran menggunakan alat Texstur Analyzer (Kusnadi 2012), (3) Protein, diukur dengan metode kjedhal.

\section{HASIL DAN PEMBAHASAN}

\section{Nilai pH}

Hasil analisa sidik ragam (lampiran 2) menunjukan bahwa lama pencelupan fillet ikan nila kedalam nitrogen cair pada hari-0 berpengaruh nyata $(\mathrm{p}<0,05)$ terhadap nilai $\mathrm{pH}$ tetapi untuk hari ke-7 tidak berpengaruh nyata terhadap nilai $\mathrm{pH}$. Setelah diuji lanjut DMRT 5\% hasil analisa $\mathrm{pH}$ fillet ikan nila dapat dilihat pada tabel 4.

\begin{tabular}{|l|l|l|}
\hline $\begin{array}{l}\text { Perakuan(lama } \\
\text { pencelupan) }\end{array}$ & \multicolumn{2}{|c|}{ PH } \\
\hline & Hari 0 & Hari 7 \\
\hline P1: freezer & $6.40 \mathrm{~b}$ & $6.06 \mathrm{a}$ \\
\hline P2: 20 detik & $6.12 \mathrm{ab}$ & $6.06 \mathrm{a}$ \\
\hline P3: 40 detik & $6.06 \mathrm{ab}$ & $6.10 \mathrm{a}$ \\
\hline P4: 60 detik & $6.04 \mathrm{a}$ & $6.08 \mathrm{a}$ \\
\hline
\end{tabular}

Keterangan : Angka yang ditandai notasi superskip huruf yang berbeda menunjukan berbeda nyata dengan uji DMRT taraf 5\%.

Tabel 4 menunjukan bahwa ada perbedaan nyata rerata nilai $\mathrm{pH}$ fillet ikan nila yang dicelupkan kedalam nitrogen cair pada hari ke-0 sedangkan untuk hari ke-7 tidak ada perbedaan nyata. nilai $\mathrm{pH}$ tertinggi pada hari ke-0 terdapat pada perlakuan P2 dengan lama waktu pencelupan selama 20 detik sebanyak 6,12. Sedangkan kadar $\mathrm{pH}$ terendah yaitu terdapat pada perlakuan P4 dengan lama waktu pencelupan selama 60 detik sebanyak 6,04. Hari ke-7 nilai tertinggi terdapat pada perlakuan P3 dengan lama waktu pencelupan selama 40 detik sebanyak 6,1. Sedangkan kadar $\mathrm{pH}$ terendah yaitu pada perlakuan P1 tanpa adanya pencelupan kedalam 
nitrogen cair dan P2 dengan lama waktu pencelupan selama 20 detik sebanyak 6,06. Diduga hal ini dikarenakan lama pencelupan dan selama penyimpanan sehingga bakteri pembusuk akan memanfaatkan asam amino dan merombaknya menjadi senyawa amonia yang bersifat basa. Penggunaan suhu rendah mempengaruhi fluktuasi nilai $\mathrm{pH}$ pada ikan nila. Penyimpanan ikan nila pada suhu rendah menyebabkan aktivitas enzim yang terdapat pada daging menjadi terhambat sehingga kemunduran mutunya berjalan lebih lambat. Semakin rendah suhu yang digunakan maka aktivitas enzim akan semakin lambat. Pada proses glikolisis, enzim sangat berperan sampai terbentuknya asam laktat. Hal ini menyebabkan akumulasi asam laktat berjalan lebih lambat sehingga penurunan $\mathrm{pH}$ ikan juga berlangsung lebih lambat. Selain itu, proses penguraian protein menjadi senyawa-senyawa yang bersifat basa oleh bakteri juga terhambat sehinga peningkatan $\mathrm{pH}$ ikan berlangsung lebih lambat (Price, 1971).

Gambar 6 menunjukan bahwa pencelupan fillet ikan nila kedalam nitrogen cair pada rerata nilai $\mathrm{pH}$ pada hari ke-0 terlihat adanya perbedaan nyata $(\mathrm{p}<0,05)$ dan untuk hari ke-7 tidak adanya perbedaan nyata. Nilai $\mathrm{pH}$ pada lama pencelupan kedalam nitrogen cair antar perlakuan mengalami penurunan, sedangkan untuk hari ke-7 nilai $\mathrm{pH}$ antar perlakuan mengalami kenaikan. Nilai $\mathrm{pH}$ pada perlakuan P1 dan P2 pada hari ke-0 setelah disimpan selama 7 hari mengalami penurunan, sedangkan perlakuan P3 dan P4 pada hari ke-0 setelah disimpan selama 7 hari mengalami kenaikan.

Gambar grafik $* * * * * * * * * * * * * * * * * * * * * * * * * *$

Hal ini diduga disebabkan oleh faktor lama pencelupan dan penyimpanan, Secara alami pH daging ikan akan akan menurun diawal masa penyimpanan kemudian naik hingga $\mathrm{pH}$ mencapai basa. Menurut Afrianto et al. (2014), perubahan kimiawi pada daging ikan diawali dengan penurunan $\mathrm{pH}$ yang terjadi karena aktivitas enzim glukosinase dalam tubuh ikan. Penyimpanan pada suhu dingin diduga berperan dalam menghambat kebusukan ikan dengan $\mathrm{pH}$ berkisar basa. Menurut Munandar et al., (2009), penggunaan suhu rendah mempengaruhi fluktuasi nilai $\mathrm{pH}$ pada ikan nila.

\section{Nilai Tekstur}

Hasil sidik ragam (lampiran 4) menujukan bahwa perlakuan pencelupan fillet ikan nila kedalam nitrogen cair pada hari ke-0 berpengaruh nyata $(\mathrm{p}<0,05)$ terhadap nilai tekstur, tetapi untuk hari ke-7 tidak berpengaruh nyata terhadap niai tekstur. Setelah diuji DMRT 5\% hasil analisa tekstur fillet ikan nila dapat dilihat pada tabel 6.

\begin{tabular}{|l|l|l|}
\hline $\begin{array}{l}\text { Perakuan(lama } \\
\text { pencelupan) }\end{array}$ & \multicolumn{2}{|c|}{ Tekstur (gf) } \\
\hline & Hari 0 & Hari 7 \\
\hline P1: freezer & $2152.88 \mathrm{a}$ & $2766.64 \mathrm{a}$ \\
\hline P2: 20 detik & $4112.21 \mathrm{~b}$ & $3500.29 \mathrm{a}$ \\
\hline P3: 40 detik & $3950.61 \mathrm{~b}$ & $3124.00 \mathrm{a}$ \\
\hline P4: 60 detik & $3779.75 \mathrm{~b}$ & $2449.25 \mathrm{a}$ \\
\hline
\end{tabular}

Keterangan : Angka yang ditandai notasi superskip huruf yang berbeda menunjukan berbeda nyata dengan uji DMRT taraf 5\%.

Tabel 6. Menunjukan bahwa adanya perbedaan nyata pada rerata nilai tekstur fillet ikan nila yang dicelupkan kedalam nitrogen cair pada hari ke-0 sedangkan untuk hari ke-7 tidak ada 
perbedaan yang nyata terhadap nilai tekstur. Pada ahri ke- 0 nilai tekstur tertinggi fillet ikan nila terdapat pada perlakuan P2 dengan lama waktu pencelupan 20 detik sebesar 4112,21 gf. Sedangkan tekstur terendah yaitu pada perlakuan P1 tanpa pencelupan kedalam nitrogen cair sebesar 2152,88 gf. Pada hari ke-7 Nilai tekstur tertinggi tertinggi fillet ikan nila terdapat pada perlakuan P2 dengan lama pencelupan selama 20 detik sebesar 3500,29 gf. Sedangkan tekstur terendah yaitu pada perlakuan P4 dengan lama pencelupan 60 detik sebesar 2449,25 gf. Hal ini disebabkan karena proses pencelupan yang semakin lama kedalam nitrogen cair sehingga cairan meresap dan menyelimuti seluruh permukaan fillet ikan dan mengakibatkan tekstur semakin keras, kemungkinan sifat nitrogen yang dapat membekukan secara cepat dan membuat kristalkristal kecil yang mampu menghambat laju drip. Menurut Warris (2000) ada tiga faktor utama yang diketahui mempengaruhi tekstur daging diantaranya panjang sarkomer, jumlah jaringan ikat atau ikatan silangnya dan tingkat perubahan proteolitik yang terjadi selama pelayuan. Luas dan jumlah lemak intramuskuler (marbling) juga akan membuat daging lebih empuk, karena lebih lembut dibandingkan otot.

Gambar 8. Menunjukan bahwa rerata pencelupan fillet ikan nila kedalam nitrogen cair pada tekstur terlihat adanya perbedaan nyata pada hari ke-0 dan tidak adanya perbedaan nyata pada hari ke-7. Nilai tekstur pada lama pencelupan kedalam nitrogen cair antar perlakuan mengalami penurunan pada hari ke-0. Pada perlakuan P1 hari ke-0 setelah disimpan selama 7 hari mengalami kenaikan sedangkan perlakuan P2, P3, dan P4 pada hari ke-0 setelah disimpan selama 7 hari mengalami penurunan. Diduga hal ini dapat dipengaruhi oleh faktor waktu lamapencelupan dan penyimpanan.

Gambar grafik $* * * * * * * * * * * * * * * *$

Pencelupan yang semakin lama kedalam nitrogen cair sehingga cairan meresap dan menyelimuti seluruh permukaan fillet ikan dan mengakibatkan tekstur semakin keras. Pada saat pembekuan terbentuk kristal-kristal es pada produk. Pada saat produk di thawing (dilelehkan), kristal-kristal es tersebut mencair dan membebaskan zat alir (drip) sehingga teksturnya menurun. Menurut Ilyas (1993), penyebab utama dari perubahan tekstur adalah ketidak mampuan pada jaringan produk yang dibekukan untuk menahan air, air pada produk beku mudah bebas selama pelelehan (thawing).

\section{Kadar Protein}

Hasil sidik ragam (lampiran 5) menunjukan bahwa perlakuan pencelupan fillet ikan nila kedalam nitrogen cair pada hari ke-0 dan ke-7 berpengaruh nyata $(\mathrm{p}<0,05)$ terhadap kadar protein fillet ikan nila. Setelah diuji lanjut DMRT 5\% hasil analisis dapat dilihat pada tabel 7.

\begin{tabular}{|l|l|l|}
\hline $\begin{array}{l}\text { Perakuan(lama } \\
\text { pencelupan) }\end{array}$ & \multicolumn{2}{|c|}{ Protein(\%) } \\
\hline & Hari 0 & Hari 7 \\
\hline P1: freezer & $20.97 \mathrm{a}$ & $19.97 \mathrm{a}$ \\
\hline P2: 20 detik & $21.14 \mathrm{a}$ & $20.78 \mathrm{~b}$ \\
\hline P3: 40 detik & $21.72 \mathrm{c}$ & $20.80 \mathrm{~b}$ \\
\hline P4: 60 detik & $21.38 \mathrm{~b}$ & $20.81 \mathrm{~b}$ \\
\hline
\end{tabular}

Keterangan : Angka yang ditandai notasi superskip huruf yang berbeda menunjukan berbeda nyata dengan uji DMRT taraf $5 \%$.

Tabel 7. Menunjukan bahwa adanya perbedaan nyata pada rerata kadar protein fillet ikan nila yang dicelupkan kedalam nitrogen cair pada hari ke-0 dan hari ke-7. Kadar protein tertinggi fillet ikan nila pada hari ke-0 terdapat pada perlakuan P3 dengan lama pencelupan 
selama 40 detik sebanyak $21,72 \%$. Sedangkan kadar protein terendah yaitu pada perlakuan P1 tanpa pencelupan kedalam nitrogen cair sebanyak 20,97\%. Kadar protein tertinggi fillet ikan nila pada hari ke-7 terdapat pada perlakuan P4 dengan lama pencelupan selama 60 detik sebesar $20,81 \%$. Sedangkan kadar protein terendah terdapat pada perlakuan P1 tanpa pencelupan kedalam nitrogen cair sebanyak 19,97\%. Diduga hal ini dapat dipengaruhi oleh faktor lama waktu pencelupan dan penyimpanan, ikan nila yang telah diolah menjadi fillet memiliki kandungan protein 16-17\% (Rohani et al., 2009). Kadar protein akan mengalami perubahan sesuai dengan lamanya waktu penyimpanan kadar protein tidak menglami perubahan yang signifikan karena lama waktu pencelupan relatif cepat sehingga bakteri pada fillet ikan belum menggunakan protein untuk pertumbuhanya oleh karena itu protein ikan belum mengalami kerusakan selama pembekuan.

Gambar grafik*************************

Gambar 9. Menunjukan bahwa pencelupan fillet ikan nila pada rerata kadar protein dengan perlakuan pencelupan kedalam nitrogen cair terlihat berbeda nyata pada hari ke-0 dan ke-7. Nilai kadar protein pada lama pencelupan kedalam nitrogen cair antar perlakuan mengalami kenaikan pada hari ke-0 dan hari ke-7 mengalami kenaikan, tetapi fillet ikan pada hari ke-0 setelah di simpan selama 7 hari mengalami penurunan kadar protein.

Peningkatan protein kemungkinan disebabkan oleh pembentukan kristal es akibat fluktuasi suhu selama penyimpanan. Pembentukan kristal tersebut dapat merusak sel-sel jaringan. Menurut Matsumoto dalam Mengistu (1987) bahwa protein miofibril (larutan garam) merupakan protein utama pada otot ikan, dimana lama penyimpanan beku protein-protein yang larut menjadi tidak larut, selanjutnya dikatakan bahwa denaturasi aktomiosin merupakan sebab utama pada penurunan kualitas ikan yang dimakan dari ikan-ikan yang disimpan.

\section{PENUTUP}

\section{Kesimpulan}

Berdasarkan hasil penelitian penggunaan nitrogen cair pada fillet ikan nila dapat disimpulkan bahwa lama pencelupan Pada hari ke-0 pengaruh perbedaan lama waktu pencelupan kedalam Nitrogen cair berbeda nyata terhadap $\mathrm{pH}$, tekstur, protein. Pada hari ke-7 tidak memberikan perbedaan nyata terdahap $\mathrm{pH}$, tekstur, tetapi berbeda nyata terhadap kadar protein. Perlakuan lama waktu pencelupan yang terbaik pada hari ke-0 terdapat pada perlakuan P2 dengan lama waktu pencelupan 20 detik, sedangkan pada hari ke-7 terdapat pada perlakuan P3 dengan lama waktu pencelupan 40 detik dengan kualitas mutu yang masih bias dipertahankan setelah dilakukan penelitian uji kimia dan mikrobiologi pada fillet ikan yang dicelupkan kedalam Nitrogen cair.

\section{Saran}

Perlu dilakukanya penelitian lanjutan, tentang pengaruh pencelupan fillet ikan nila kedalam nitrogen cair terhadap lama waktu penyimpanan dalam jangka waktu yang lebih lama. 


\section{DAFTAR PUSTAKA}

Afrianto E, Liviawaty E, Suhara O, Hamdani H. 2014. Pengaruh suhu dan lama blansing terhadap penurunan kesegaran fillet tagih selama penyimpanan pada suhu rendah. Jurnal Akuatika 5(1): 45-54.

AOAC, 2005. Official Methods of Analysis. Association of official Analytical Chemists INC, Washington, D.C.

Ilyas, S., 1993. Teknologi Refrigerasi Hasil Peternakan. Badan Penelitian Pengembangan Pertanian dan Pusat Penelitian Pengembangan Peternakan, Jakarta.

Irianto, E. H. dan Soesilo. 2007. Dukungan Teknologi Penyediaan Produk Perikanan.[Seminar].Bogor. [Jurna]

Kusnadi, D.C., Bintoro, V.P. dan Al-Baarri, A.N. 2012. Daya Ikat Air, Tingkat kekenyalan dan Kadar Protein pada Bakso Kombinasi Daging Sapi dan Daging Kelinci. Jurnal Aplikasi Teknologi Pangan (1): 28-31.

Matsumoto JJ, Noguchi SF.1992. Cryostabilization of protein in surimi. Di dalam : Surimi Technology. Lanier TC, Lee CM, editors. New York : Marcel Dekker

Moeljanto, 1992. Pengawetan dan Pengolahan Hasil Perikanan. PT. Penebar Swadaya, Jakarta.

Munandar. A., Nurjannah, dan M. Nurilmala. 2009.Kemunduran Mutu Ikan Nila (Oreochromis niloticus) pada Penyimpanan Suhu Rendah dengan Perlakuan Cara Kematian dan Penyiangan. Jurnal Teknologi Pengolahan Hasil Perikanan Indonesia. (12) 2.

Price JF and BS Schweigert. 1971. The Science of Meat and Meat Products. Second Ed. W.H. Freeman an Co., San Francisco.

Rohani, A.C., O. Normah, T. Zahrah, C.M.C Utama and I. Saadiah. 2009. Quality of Fish Fillet from Pond-Raised Red Tilapia and its Utilisation in the Development of Value-Added Product.J.Trop.Agric and Food Sci. 37 (2) :153-161

Warris, P. D. 2000. Meat Science. An Introductory Text. New York: CABI Pub. Inc.

Xu, Fei. , Wang, Zhang. , Xu, Shiying and Sun, D.W. 2001.Cryostability of frozen concentrated orange juices producedby enzymatic process. Journal of Food Engineering 50:217-222. 